\title{
Back to restitutives (again): A syntactic account of restitutive and counterdirectional verbal particles in Hungarian
}

\author{
VERONIKA HEGEDÜS*
}

MTA Research Institute for Linguistics, Budapest, Hungary

Received: October 14, 2019 • Accepted: May 19, 2020

(C) 2020 The Author(s)

\section{ABSTRACT}

This paper discusses two Hungarian verbal particles that belong to the semantic group of repetitive elements. The main focus is on the verbal particle újra 'again', which has primarily been discussed as an adverb with repetitive and restitutive meanings (with the exception of Csirmaz 2015) but can be a verbal particle, which is distinct both from the adverb and from most other verbal particles. The verbal particle vissza 'back', which expresses counterdirectionality will be claimed to be like typical, primarily directional verbal particles and to be a part of the result component of the argument structure. Úra 'again' as a verbal particle is analyzed on a par with some nondirectional particles and idiomatic resultative phrases that are inserted into the structure in a functional projection below the external argument.

\section{KEYWORDS}

repetitive, restitutive, verbal particle, resultative, Hungarian

\section{INTRODUCTION}

This paper deals with the syntax of Hungarian verbal particles that belong to the larger semantic group of repetitive elements. The main focus is on the verbal particle újra 'again', an element that has primarily been discussed as an adverb with repetitive and restitutive meanings but has a

\footnotetext{
*Corresponding author. E-mail: hegedus.veronika@nytud.hu
} 
verbal particle use as well (Horvath \& Siloni 2011 make note of its existence and Csirmaz 2015 discusses it in some detail, without analyzing it specifically as a particle). The other, semantically related, verbal particle under consideration here is vissza 'back', which expresses counterdirectionality, another semantic subtype of repetitives.

It will be claimed that these two particles do not only have distinct semantic properties, where one is restitutive (with minor broader repetitive use) and the other is counterdirectional (with marginal non-directional restitutive use), but they are also syntactically different. The verbal particle újra 'again' is more restricted than directional particles of the language are, and, thus, will be analyzed on a par with a few recently grammaticalized particles and idiomatic resultative phrases that are not secondary predicates in the complement of $\mathrm{V}$ but are inserted into the structure in a low functional projection above VP. Meanwhile, vissza 'back' behaves exactly like the other, primarily directional (and telicizing) verbal particles in Hungarian, and is part of the resultative component of the argument structure in the complement of the verb.

These results contribute to the theoretical discussion on repetitive elements and the proposals concerning their interpretational possibilities in two ways. On the one hand it will be shown that both structural and lexical differences can be found among restitutive elements. The element ujra 'again' can be both an adverb and a verbal particle in Hungarian with a restitutive meaning, and it has different structural properties and different lexical specifications as such. On the other hand, even when it comes to verbal particles with (different) repetitive meanings, we find differences that support structural distinctions, as well. Relatedly, the second point of the paper concerns the structural properties of Hungarian verbal particles. Verbal particles are not structurally uniform; the restitutive újra 'again' and the counterdirectional vissza 'back' are inserted into the structure in different places, lending further support to previous assumptions that some verbal particles are not secondary predicates introducing their own subject but are predicate modifiers.

The paper is structured as follows. Section 2 will give a brief general summary on Hungarian repetitives, then Section 3 will turn to the use of újra 'again' as a verbal particle, compared to the adverb, and a syntactic analysis of the verbal particle will be proposed. This account distinguishes it both from the adverbial use of ujra 'again' and from many other particles, based on its distribution and semantic properties. Section 4 will relate the proposal about újra (i) to the other repetitive verbal particle vissza 'back', providing evidence that vissza is (mostly) counterdirectional, and proposing a syntactic account that treats it on par with other directional particles, and (ii) to other verbal particles that have been claimed to be structurally similar to the restitutive particle. Section 5 will summarize the conclusions of the paper.

\section{REPETITIVES IN HUNGARIAN: A BRIEF OVERVIEW}

Repetitive adverbs, such as English again, have received a lot of attention in recent decades, partly due to the fact that their interpretation possibilities have been used as empirical evidence for a syntactically decomposed argument structure of resultative and causative events (but see Horvath \& Siloni 2011 for arguments against such a decomposition for some causatives). The basic observation is that in some contexts sentences containing again are ambiguous between a 
repetitive reading and a restitutive reading. (1) illustrates this observation with the two possible readings of the sentence.

(1) John opened the door again.

a. John opened the door and that had happened before. (repetitive reading)

b. John opened the door and the door had been open before. (restitutive reading)

There have been various approaches to the possible analyses to account for the different reading possibilities. There is a syntactic approach, which assumes that the different readings are due to different structural positions that again and similar adverbs can occupy and its lexical meaning is constant. This was proposed by von Stechow (1996) for German wieder 'again' and similar elements. According to this analysis an adverb like again modifies the result or endstate subevent when it is restitutive and is inserted higher than the external argument (above VoiceP according to von Stechow 1996) when it is only repetitive (i.e., necessarily includes the agent in the repeated event). Another approach attributes the different interpretations available to repetitive elements to the existence of a lexical ambiguity, with different semantic properties for again under the two readings (Fabricius-Hansen 2001). Recently, it has been proposed that both syntactic and semantic accounts are needed, as we need both structural and lexical distinctions to adequately account for all possibilities of repetitive interpretations broadly understood (Beck 2005; Patel-Grosz \& Beck 2014).

For Hungarian, Csirmaz (2015) provided a list and description of repetitive adverbs (2) and proposed an account, subscribing to the view that structural differences are behind the basic distinction between repetitive and restitutive readings. The adverbials in (2a) here are of various morphological forms, and only two of them have a restitutive reading besides the repetitive one; these are megint and újra 'again'. The repetitive reading that indicates counterdirectionality, i.e., reversal of direction, is expressed by the element in (2b), which is a verbal particle. As has been argued by Patel-Grosz \& Beck (2014), Kutchi Gujarati is a language that uses a single form to encode all three meanings; here the distributions are more complex.
a. megint, ismét, újra, újfent 'again'; még egyszer 'once more'
b. vissza 'back'

Hungarian repetitive adverbs can appear in various positions in the clause, as Csirmaz (2015) describes, they can appear after the structural Topic, after quantifiers, and postverbally, as well.

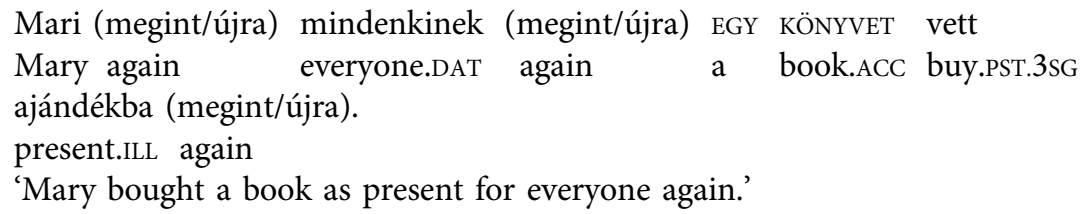

Two adverbs, megint and újra 'again' can have a restitutive reading but its availability is more restricted than that of the repetitive reading. When testing their structural position with respect to other adverbs, it turns out that the restitutive reading is only available in a position below high 
adverbs, e.g. carefully, (4). According to the analysis proposed by Csirmaz (2015), following others, a repetitive element has to be inserted low in the structure in order to have a restitutive reading, thus favoring a structural approach to accounting for the different readings. She argues that only megint and újra are inserted low enough in the structure to be restitutive, the other Hungarian repetitive adverbs are always inserted higher than the agent. The sentence in (4) contains a verbal particle preceding the verb, and when the adverb megint 'again' is inserted higher than that but lower than the adverb ovatosan 'carefully', it can have a restitutive interpretation, i.e., it can refer to the restoration of an end state with a possibly different agent (or no agent involved).

Feri (megint) óvatosan (megint) ki nyitotta az ablakot. Feri again carefully again out opened the window.ACC 'Feri opened the window carefully again.' (Csirmaz 2015: 272)

This is a relevant point since Csirmaz (2015) notes that when we have újra 'again' in a sentence instead of megint, it can also fill the preverbal position occupied by verbal particles and other resultative elements (among others). Csirmaz (2015) also pays attention to this use of úra 'again', calling it a verbal modifier in the clause, in sentences such as (5).
Feri újra-írta
a levelet.
Feri again-write.PST.DEFOBJ.3sG the letter.ACC
'Feri rewrote the letter.'

Verbal modifiers (VMs) are constituents that are found in the immediately preverbal position in neutral Hungarian sentences, i.e., in clauses that do not contain negation, focus or wh-interrogatives (Kálmán 1985; É. Kiss 2002). Verbal modifiers have received a lot of attention in Hungarian syntax, and among them, verbal particles have been well-described (see e.g. É. Kiss 2004, 2006 for recent general proposals). What Csirmaz (2015) identifies as the verbal modifier use of újra can be considered more specifically to be a verbal particle and not simply an idiomatic resultative phrase, since it is functional in meaning and, relatedly, it is used productively with various types of verbs (these being descriptive/historical criteria for identifying verbal particles (Forgács 2004; D. Mátai 1989, 2011). ${ }^{1}$

Úra as a verbal particle can always be restitutive and it may have a very limited non-restitutive repetitive interpretation (cf. Csirmaz 2015). The fact that the same element can be both an adverb and a verbal modifier/particle necessitates a lexical distinction, as we will see, since the difference does not only lie in the structural position of the adverb compared to the particle.

Von Stechow (1996) analyzed restitutive adverbs as modifiers of the result subevent, introduced under the agent. Csirmaz (2015) merges the VM újra 'again' under the verb,

\footnotetext{
${ }^{1}$ Forgács (2004) takes the grammaticalization path from an idiom chunk to a particle to be a productive source of new particles, and this paper complements his view with a structural proposal on how this may also result in a different structural configuration due to its source. The fact that újra was originally a resultative predicate and that it can be inserted lower in the structure were definitely important in its development into a particle.
} 
although not specifically as a verbal particle, but as a modifier of the result. Since verbal particles have widely been regarded as secondary predicates, the question arises if VM újra in (5) can be analyzed as one, motivating its insertion not as a modifer but as a predicative head. In Section 3 , I will look at the differences between the uses of ujra as an adverb and as a verbal particle and the distribution of újra as a verbal particle (as compared to other particles) and propose an analysis to account for its properties. However, the structural distinctions need to go even further, as the counterdirectional element vissza 'back' is also a verbal particle but different from the restitutive particle.

\section{3. ÚJRA AS A VERBAL PARTICLE}

\subsection{The origin of the form}

The form újra can be decomposed into the adjective $u j$ 'new' and the sublative suffix -ra (6), which is the suffix that appears on resultative secondary predicates in general (7). However, neither the adverb nor the particle újra 'again' is compositional in meaning and transparently bimorphemic for speakers of present-day Hungarian, and henceforth it will be glossed as again consistently. ${ }^{2}$
Péter [új-ra] festi
a kerítést.
Peter new-SUB paint.DEFOBJ.3SG the fence.ACC
'Peter is painting the fence again.'
Péter piros-ra festi
a kerítést.
Peter red-sub paint.DEFOBJ.3SG the fence.ACC
'Peter is painting the fence red.'

Úra as a particle is fairly young, and the form itself is a new development in general. D. Mátai (2011, 244) puts the appearance of újra as an adverb to the Middle Hungarian period (15261772), noting that it was originally a lexical word with an adverbial suffix (the sublative suffix). She lists the particle újra among those particles that grammaticalized in the Modern Hungarian period (since 1772). This is relevant for the present inquiry for at least two reasons: (i) the item has not developed from a directional (goal-denoting) postpositional phrase (PP), but from a

${ }^{2}$ The form is compositional in meaning and transparently bimorphemic, however, when it is used in elliptical noun phrases, such as the ones in (i).

(i) a. Anna a régi szék-re ült le, Mari pedig az új-ra.

Anna the old chair-sub sit.PST.3sg down Mari yet the new-sub

'Anna sat down on the old chair, and Mary on the new one.'

b. Péter új-ra cserélte a régi TV-jét.

Peter new-SUB exchange.PST.DEFOBJ.3sg the old TV-POss.3sG.ACC

'Peter replaced his old TV with a new one.' 
resultative phrase; and (ii) its form has not become reduced. Its closest syntactic and semantic parallels are probably not to be found among the older directional particles whose lexical stem and morphological structure is either unrecognizable (e.g. meg 'orig. back', which is fully functional now, or el 'away') or still quite transparent (e.g. hozzá 'towards', végig 'along, to the end') but among more recent, resultative particles (see e.g. Forgács 2004).

\subsection{How is the verbal particle different from the adverb?}

3.2.1. Preverbal position and interpretation. The particle újra 'again' is different from the adverb in that it forms one stress unit with the verb it precedes. ${ }^{3}$ Under some circumstances they can appear in exactly the same syntactic environment but their stress properties are different, as in (8) compared to (9): the particle forms one stress unit with the verb, with one word stress on the left edge, while the adverb and the verb each have their own word stress.
Péter 'újra 'ír
egy levelet.
Peter again write.3sG a letter.ACC
'Peter is writing a letter again.'

(9)
Péter 'újra-ír
egy levelet.
Peter again-write.3sG a letter.ACC
'Peter is rewriting a letter.'

There is also a difference in meaning between the two sentences here. In (9), the indefinite phrase has higher scope, so the event is about a certain letter being reworded by Peter, this is a restitutive reading. In (8), the adverb has higher scope, that is we have repeated events of Peter writing a letter, which is a repetitive reading.

This is not to say that the adverb is always repetitive and cannot have a restitutitve reading; Csirmaz (2015) established that the adverbs újra and megint can both be repetitive and restitutive under certain conditions. When the adverb újra appears with telic predicates, e.g. ones that include a verbal particle already, the clause can also have a restitutive interpretation, which makes (10) ambiguous between a repetitive reading (where Anna had opened the door earlier and then opened it again) and a restitutive reading (where the door was open, someone closed it, and then Anna opened it).
Anna újra ki-nyitotta
az ajtót.
Anna again out-open.PST.DEFOBJ.3sG the door.ACC
'Anna opened the door again.'

\footnotetext{
${ }^{3}$ The particle and the verb are generally written as one word when the particle is immediately before the verb but they will be consistently separated with a hyphen here for the sake of transparency. Adverbs, on the other hand, are separate words.
} 
That is, the difference between the adverb and the particle újra cannot be drawn strictly along the lines of the available readings. However, an important difference between újra as an adverb and as a verbal particle concerning interpretation lies in their (dis)ability to telicize an event.

As an adverb, újra does not telicize the event it modifies. This can be shown by trying to add different temporal modifiers to the predication: the for-PP is grammatical, while the equivalent of the in-PP is ungrammatical in the sentences in (11). The sentence in (11b) is ungrammatical without the adverb újra as well, as Hungarian predicates are generally atelic if they do not have the result lexicalized separately, e.g. by a particle (see É. Kiss 2006; Kardos 2016 a.o.). Read the book is atelic without a particle in a neutral sentence, and the adverb újra does not change that property.
a. Anna 10 percen
át ('újra) 'olvasta
a novellát.
Anna 10 minute.sup over again read.PST.DEFOBJ.3SG the short.story.ACC
'Anna read the short story for 10 minutes (again).'
b. *Anna 10 perc alatt ('újra) 'olvasta
a novellát.
Anna 10 minute under again read.PST.DEFOBJ.3SG the short.story.ACC
'Anna read the short story in 10 minutes (again).'

With verbs of creation, the situation is slightly different. When a creation verb such as ir 'write' has an indefinite object, the predication can get both an atelic and a telic interpretation (cf. Kardos 2016). When we add the repetitive adverb, it does not change the properties of the sentence (12), both types of adverbs from above can be used and give a grammatical sentence.
a. Anna 10 percen át ('újra) 'írt Anna 10 minute.sup over again write.PST.3sG a letter.ACC 'Anna was writing a letter for 10 minutes (again).'
b. Anna 10 perc alatt ('újra) 'írt egy levelet. Anna 10 minute under again write.PST.3SG a letter.ACC 'Anna wrote a letter in 10 minutes (again).'

However, when ujra is a particle, it can telicize the event on its own, a property generally shared by verbal particles and lexical resultatives. Using the same adverbs as before can show this difference (13). If we take the examples in (11) and use the particle instead of the adverb, the grammaticality of the examples is reversed: the only interpretation available is the telic one.
a. *Anna 10 percen át 'újra-olvasta a novellát. Anna 10 minute.sup over again-read.PST.DEFOBJ.3SG the short.story.ACC 'Anna re-read the short story for 10 minutes.'
b. Anna 10 perc alatt 'újra-olvasta a novellát. Anna 10 minute under again-read.PST.DEFOBJ.3SG the short.story.ACC 'Anna re-read the short story in 10 minutes.'


With verbs of creation, where both readings were available in (12), again the telic reading is preferred when újra is added as a particle (14). For some speakers the telic reading is the only available option, for some others the atelic adverb is slightly degraded but not ungrammatical. ${ }^{4}$
a. \%?Anna 10 percen át újra-írt egy levelet.
Anna 10 minute.sup over again-write.PST.3SG a letter.ACC 'Anna rewrote a letter for 10 minutes.' Anna 10 minute under again-write.PST.3SG a letter.ACC 'Anna rewrote a letter in 10 minutes.'
b. Anna 10 perc alatt újra-írt egy levelet.

In this respect, újra as a particle behaves like other particles and telicizes the otherwise atelic event (pace the possible variation mentioned above). This is a semantic property that distinguishes the verbal particle from the adverb, a distinction consistent with general properties of particles and adverbs in Hungarian. It also possibly draws a lexical difference between the adverb and the verbal particle use of újra, since the adverb can only be restitutive when adjoined to a telic event, while the verbal particle takes part in telicizing the event.

3.2.2. Co-occurence with (other) VMs. Újra as a verbal particle, forming one phonological unit with the verb cannot co-occur with another verbal particle or resultative phrase in the preverbal position, identically to the behavior of other verbal particles. As Csirmaz $(2015,282)$ notes, it cannot co-occur with particles because they compete for the same syntactic position (the VM position). The sentence in (15a) involves the verbal particle use of újra and shows that the combination of two particles in the immediately preverbal position leads to ungrammaticality. Notably, it is also ungrammatical to have the other particle in the postverbal field (15b).
a. *Péter újra-meg-írt egy levelet.
Peter again-PERF-write.PST.3SG a letter.ACC
'Peter rewrote a letter (completely).'
b. *Péter újra-írt egy levelet meg.
Peter again-write.PST.3SG a letter.ACC PERF
'Peter rewrote a letter (completely).'

The verbal particle újra cannot co-occur preverbally with regular resultative secondary predicates, either. While both the particle (16a) and the resultative (16b) are well-formed on their own with a verb such as fest 'paint', they cannot be preverbal together in either possible order (17a)-(17b).

\footnotetext{
${ }^{4} \mathrm{~A}$ larger-scale data collection may be needed in order to determine whether this variation is consistently observed with different verb classes when újra is present, and to see whether the restitutive reading is available, or perhaps a repetitive reading replaces it, for those who accept the atelic adverb with újra as a particle. The reason for this apparent interspeaker variation is left as an open issue for now.
} 

a. Anna újra-festette
a kerítést.
Anna again-paint.PST.DEFOBJ.3SG the fence.ACC
'Anna repainted the fence.'

b. Anna zöld-re festette a kerítést.

Anna green-SUB paint.PST.DEFOBJ.3SG the fence.ACC

'Anna painted the fence green.'
a. *Anna zöld-re újra-festette a kerítést.
Anna green-SUB again-paint.PST.DEFOBJ.3SG the fence.ACC
'Anna repainted the fence green.'
b. *Anna újra-zöldre-festette a kerítést.
Anna again-green.sub-paint.PST.DEFOBJ.3SG the fence.ACC
'Anna repainted the fence green.'

This is perfectly in line with what we would expect of this item because of its resultative origin and morphological form, assuming that it is obligatorily a VM. Two preverbal particles or a combination of a particle and a resultative is generally prohibited from the preverbal position.

Two notes are in order here on the distribution of újra and (other) VMs. Firstly, újra as an adverb is perfectly well-formed in the same clause with a preverbal particle or resultative secondary predicate (18), which distinguishes it from the particle.
a. Anna újra zöld-re festette a kerítést.
Anna again green-SUB paint.PST.DEFOBJ.3SG the fence.ACC
'Anna painted the fence green again.'
b. Anna újra le-festette a kerítést.
Anna again down-paint.PST.DEFOBJ.3SG the fence.ACC
'Anna painted the fence (completely) again.'

This is generally true for adverbs modifying the predicate: they can be followed by a VM-V unit as shown in (19).
a. Anna gyorsan zöld-re festette a kerítést.
'Anna quickly painted the fence green.'
Anna quickly green-SUB paint.PST.DEFOBJ.3SG the fence.ACC
b. Anna gyorsan le-festette a kerítést.
Anna quickly down-paint.PST.DEFOBJ.3SG the fence.ACC
'Anna quickly painted the fence (completely).'

Secondly, while ujra is not compatible with another particle in the same clause (15b), it is to some extent compatible with another lexical resultative, when that is postverbal (20). This is actually not unusual for particles, as most of the other particles can also easily co-occur with resultative secondary predicates (21). The postverbal resultative can be an afterthought, a 
constituent outside the clause. ${ }^{5}$ In that case the resultative phrase zöldre 'to green' is not in the scope of the restitutive element in (20), so it is not necessarily the case that the fence used to be green, then it was a different color and then it gets painted green again; it could have been any color earlier, it is only stated that it becomes green as a result of being repainted. Under the other interpretation, the postverbal resultative phrase is part of the clause (in both (20) and (21)), the lexical resultative specifies the result state, and is in the scope of the restitutive particle, meaning that the fence being green is the state that is being repeated in (20).

Anna újra-festette a kerítést zöld-re.
Anna again-paint.PST.DEFOBJ.3SG the fence.ACC green-SUB
'Anna repainted the fence green.'
Anna le-festette
a kerítést zöldre.
Anna down-paint.PST.DEFOBJ.3SG the fence.ACC green-suB
'Anna painted the fence green.'

Hegedüs (2013) proposed that such co-occurence of a particle and a resultative does not violate the general restriction that only one delimiter per clause is allowed (Levin \& Rappaport Hovav 1995) since the particle and the resultative belong to a single phrase, they just lexicalize two parts of one secondary predicate. Following this, two particles are excluded since they would lexicalize the same part of the secondary predicate, they compete for the same position in the secondary predicate at lexical insertion (the apparent counterexamples will be discussed in Section 4.2).

To sum up, its preverbal distributional properties distinguish újra as a verbal particle from when it is an adverb. The adverb bears a word stress independent of the verb, while the particle forms one stress unit with it, with the stress on the particle. The adverb can co-occur with a preverbal particle or resultative secondary predicate, which means that it is not a VM, while the particle needs to be preverbal on its own, it cannot co-occur with another particle in the same clause at all and can only co-occur with a lexical resultative if that resultative is postverbal. These properties make them similar to other adverbs and verbal particles, respectively.

Verbal particles are generally characterized as being productive (i.e., used with many verbs) and having a non-lexical, functional meaning. The particle under consideration has these properties: ujra is quite productive with various types of verbs, and its meaning is not the lexical, compositional one, but it has a restitutive meaning instead. However, újra as a verbal particle is more restricted than other particles in some respects, which will be discussed in 3.3.

\subsection{Restrictions on the verbal predicate}

3.3.1. Ditransitives. A property of the verbal particle újra noted by Csirmaz (2015) is that it generally cannot appear with ditransitive verbs, ${ }^{6}$ for example, it cannot be used with ad 'give' (22). I agree with Csirmaz (2015) on taking this to be a semantic restriction, namely, a resriction

\footnotetext{
5Some speakers may prefer or always have an intonational break before the postverbal resultative in (20), signaling that it is an afterthought; however, the intonational pattern without a break is generally also available to speakers.

${ }^{6}$ This is a property shared by the English prefix re- (Marantz 2007).
} 
that this particle cannot co-occur with "once-only" predicates. It is a once-only predication in (22) in the sense that possession is transferred, the accusative-marked object will become the possession of the dative-marked complement, and once this is established it cannot be reestablished with the same object. Since the restitutive particle necessarily has narrow scope with respect to the direct object, i.e., the indefinite object here is interpreted as specific, transferring the object is a "once-only" predication (Csirmaz 2015).

$$
\begin{aligned}
& \text { *Péter újra-adott egy könyvet Mari-nak. } \\
& \text { Peter again-give.PST.3SG a book.ACC Mary-DAT } \\
& \text { 'Peter gave a (certain) book to Mary again.' }
\end{aligned}
$$

The restriction prohibiting the verbal particle újra from appearing with ditransitives does not generally apply to verbal particles, it is specific to this restitutive one. Ditransitive constructions, including ad 'give', often include a directional particle that denotes the direction of the transaction and telicizes the event (23).
a. Péter oda-adott
Peter there.to-give.PST.3SG a book.ACC Mary-DAT
'Peter gave a book to Mary.'
egy könyvet Mari-nak.
b. Péter át-adott egy könyvet Mari-nak.
Peter over-give.PST.3SG a book.ACC Mary-DAT
'Peter handed a book to Mary.'

The claim that we are dealing with a semantic (or lexical) restriction rather than a syntactic one on the co-occurence of ditransitives and újra is supported by the fact - also mentioned by Csirmaz (2015) - that the verb küld 'send' is an exception to some extent, as long as one can interpret the event as sending the same thing more than once, so we are not really dealing with a once-only predication. This interpretation is easily accessed when it comes to sending emails (24) but it requires considerably more context if we are talking about sending a certain postcard (25).

$$
\begin{aligned}
& \text { Péter újra-küldött egy emailt } \text { Mari-nak. } \\
& \text { Peter again-send.PST.3SG a email.ACC } \\
& \text { 'Peter resent an email to Mary.' }
\end{aligned}
$$

$$
\begin{aligned}
& \text { \#Péter újra-küldött egy képeslapot Mari-nak. } \\
& \text { Peter again-send.PST.3SG a postcard.ACC Mary-DAT } \\
& \text { 'Peter sent a (certain) postcard to Mary again.' }
\end{aligned}
$$

In sum, verbal particle újra needs to modify a predication that is not "once-only" due to its low scope (for more on the scopal properties, see Csirmaz 2015), and therefore is restricted with ditransitive verbs, which is a restriction not shared by other, typical verbal particles. 
3.3.2. Unergatives and unaccusatives. Another restriction noted by Csirmaz (2015) is that the particle újra cannot appear with unergative verbs (26) or with causatives of unergatives (27).

*Feri újra-nevetett.

Feri again-laugh.PST.3SG

'Feri laughed again $_{\text {rest.' }}$ (cf. Csirmaz 2015)

\footnotetext{
*Feri újra-nevettette Marit.

Feri again-laugh.CAUS.PST.DEF.OBJ.3SG Mary.ACC

'Feri made Mary laugh again.'
}

This is a curious property; however, to the extent that we can assert that this particle is (overwhelmingly) restitutive in meaning, it is empirically analogous to what von Stechow (1996) observed about German wieder 'again', namely, that wieder is ambiguous between repetitive and restitutive readings with unaccusative verbs but is unambiguously repetitive with unergatives. This is also a property shared by the English restitutive prefix re- (Horn 1980; Marantz 2007). The restitutive reading requires the presence of a result state, which is unavailable with simple unergatives. The fact that causatives do not allow for the restitutive interpretation seems to support Horvath and Siloni's (2011) claim that these morphological causatives are not decomposed in syntax, there is no result state in syntax that could be modified.

It was shown by Surányi (2009a) that the adverb újra 'again' exhibits similar behavior to the German facts when it appears in clauses with directional verbal modifiers (particles or lexical PPs): it is ambiguous with unaccusative verbs but is only repetitive with unergative verbs. The examples in (28) are used by Surányi (2009a) to illustrate this difference (the adverb is postverbal to facilitiate the restitutive reading) and are taken as evidence that the Direct Object Restriction on resultatives holds. According to this generalization, a resultative phrase can be predicated of an object but not of a subject or an oblique phrase (Levin \& Rappaport Hovav 1995). Unergatives lack an object, so the restitutive reading of the adverb is impossible.

(The dog was hidden into a pit. It climbed out, and then ...)

a. Bele zuhant újra a gödörbe. (repetitive/restitutive) into.it fell-3SG again the pit.into

'It fell into the pit again.'

b. Bele ugrott újra a gödörbe. (repetitive/\#restitutive) into.it jumped-3SG again the pit.into 'It jumped into the pit again.'

So far, we have seen data that have been taken as evidence that újra as a particle is different from its adverb use and behaves like verbal particles do. However, unavailability with unergatives is not a general property of verbal particles in Hungarian. Often they change the argument structure of the verb (or, put differently, a particle-verb has a different argument structure than its particle-less counterpart) and make transitive verbs out of unergative ones (29). 

Mari ki-nevette
Annát.
Mary out-laugh.PST.DEFOBJ.3SG Anna.ACC
'Mary laughed at Anna.'

In this respect, újra is not like regular, telicizing particles, it seems to need a transitive predicate but it cannot be the result predicate in the complex event. This is also confirmed by its ungrammaticality with psych verbs or with verbs like love or hate, which can be used with other particles as predicates describing dynamic events, where the particle creates a telic event (30)-(31) as the head of secondary predication in the complex argument structure (see 3.4).
a. *A villámlás újra-ijesztette
Annát. the lightning again-frighten.PST.DEFOBJ.3SG Anna.ACC 'The lightning made Anna frightened again.'
b. A villámlás meg-ijesztette Annát. the lightning PERF-frighten.PST.DEFOBJ.3SG Anna.ACC 'The lightning frightened Anna.'
a. *Mari újra-szerette Pétert.
Mary again-love.PST.DEFOBJ.3SG Peter.ACC
'Mary fell in love with Peter again.'
b. Mari meg-szerette Pétert.
Mary PERF-love.PST.DEFOBJ.3SG Peter.ACC 'Mary started to love Peter.'

Furthermore, when we take motion verbs, we find that újra can only be used as a particle with those verbs that have a transitive version with an object that measures out the event. So, fut 'run' and sétál 'walk' are generally used intransitively, and then they cannot appear with this particle (32).
a. *Anna újra-futott.
Anna again-run.PST.3SG

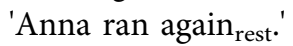
b. *Anna újra-sétált.
Anna again-walk.3SG
'Anna walked again $_{\text {rest.' }}$

Motion verbs are often used with a directional lexical PP or with a directional particle, denoting the endpoint of movement (33), in which case, we are arguably dealing with an unaccusative predication and the particle is the secondary predicate (Hegedüs 2013). We have already seen that ujra as a particle cannot co-occur with another particle in the same clause, and (34a) shows 
that it cannot co-occur with a postverbal directional PP, either. Other particles, e.g. el 'away' can co-occur with postverbal directional PPs (34b) (similarly to the co-occurence of particles and resultatives; see also Hegedüs 2013).

a. Anna a sarok-ig futott.

Anna the corner-TER run.PST.3SG

'Anna ran to the corner.'

b. Anna el-futott

Anna away-run.PST.3SG

'Anna ran away.'
a. *Anna újra-futott a sarok-ig.
Anna again-run.PST.3SG the corner-TER
'Anna ran to the corner again.'

b. Anna el-futott a sarokig.

Anna away-run.PST.3SG the corner-TER

'Anna ran up to the corner.'

Some motion verbs can also be used quasi-transitively, with an accusative complement that measures out (and potentially telicizes) the event, and in such cases újra can be used as a particle with the motion verb. Its meaning in (35) can be repetitive, if Anna ran the last lap once and then ran the last lap again. While the repetitive meaning seems more prominent, it can also be restitutive, if one imagines a scenario when someone else was running the last lap in a relay competition but then for some reason Anna did the last lap again.
Anna újra-futotta
az utolsó kört.
Anna again-run.PST.DEFOBJ.3SG the last lap.ACC
'Anna re-ran the last lap.'

A further restriction is that úra cannot appear with unaccusative motion verbs to denote that the endpoint of the motion is one that was held earlier (36). In these counterdirectional contexts we find the particle vissza 'back', as will be discussed in Section 4.1.

$$
\begin{aligned}
& \text { *A hőmérséklet újra-esett. } \\
& \text { the temperature again-fall.PST.3SG } \\
& \text { 'The temperature dropped again.' }
\end{aligned}
$$

The adverb újra 'again' can be used with these verbs but then we have a repeated atelic event and not one that reaches a result state (37).

A hőmérséklet újra esett.

the temperature again fall.PST.3SG

'The temperature dropped again.' 
It is not the case that újra cannot be a particle with unaccusatives in general, it just cannot be interpreted as a (spatial) endpoint (unsurprisingly) or a result state, its meaning is more functional.

Thus, újra as a verbal particle is more restricted than most, directional particles as it cannot be used with unergative verbs, due to the fact that it requires an internal argument in the predication, similarly to other resultative phrases. Unlike some other resultatives (including many verbal particles), however, it does not seem to be able to change the argument structure of the verb, it does not introduce a theme into the structure. Because of its semantics, it also cannot encode an endpoint in the event, so its use with unaccusative verbs is also limited.

3.3.3. Újra 'again' versus újjá 'anew' with the same verbs. With unaccusative verbs that do not require an endpoint, there is an interesting division of labor between újra and another resultative predicate that is on its way to becoming a particle, újjá 'anew'.

The fact that there are two resultatives with the adjective 'new' is due to Hungarian having another productive way to create resultative secondary predicates out of adjectives in general, with the addition of the translative suffix -vá/vé. Resultatives with this suffix are less productive than those with the sublative one: it is used with resultative complements of some unaccusative (or middle) verbs and their transitive counterparts. Although this other particle can be used in contexts where it might seem as an alternative of újra, if újra were in any way compositional in its interpretation, there is a consistent meaning difference.

Ujjá is a lexical, compositional secondary predicate, and has retained its lexical meaning in its use as a particle. Ujra, however, has a noncompositional functional interpretation. The clause in (38) includes the particle újra and can be used when the band was on hiatus and got together again, so it is compatible with the additional information saying that nothing changed within the band. (39) with újjá, however, necessarily means that there is some change, e.g. a new member is joining the band, but it does not imply that the band was not constantly together, in fact it means that the band has been together as is for ten years and now there is some change happening.
A zenekar 10 év után újra-alakul - változatlan felállásban.
the band 10 year after again-form.3SG - unchanged up.standing.INE
'The band re-forms after 10 years - with the same line-up.'
A zenekar 10 é
után újjá-alakul
- új tag
lép be.
the band 10 year after new.TRA-form.3SG - new member step.3SG into
'The band is reformed after 10 years - a new member joins.'

Were the continuations of the sentences switched, the following would happen. (40) is completely grammatical, the band was not together, now it gets together again, and additionally a new member joins. However, (41) is infelicitous (or even ungrammatical) since the continuation contradicts the first part of the sentence.
A zenekar 10 é
után újra-alakul
- új
tag
lép be.
the band 10 year after again-form.3SG - new member step.3sG into
'The band re-forms after 10 year - (and) a new member joins.' 


$$
\begin{aligned}
& \text { \#A zenekar } 10 \text { év után újjá-alakul - változatlan felállásban. } \\
& \text { the band } 10 \text { year after new.TRA-form.3SG - unchanged up.standing.INE } \\
& \text { 'The band is reformed after } 10 \text { years - with the same line-up.' }
\end{aligned}
$$

The same meaning difference is found when the two particles combine with verbs such as születik 'be born', épül 'be built' (and its transitive counterpart épit 'build'), which can be used with both of them. This is further illustrated with the contrast between the examples in (42) and (43).

$$
\begin{aligned}
& \text { Az ember egyes vallások szerint a halál után újra-születik. } \\
& \text { the person some religion.PL according.to the death after again-be.born.3sG } \\
& \text { 'According to some religions, one is reborn after death.' }
\end{aligned}
$$

Ha elmész egy gyógyfürdőbe, (teljesen) újjá-születsz.

if away.go.2SG a health.spa.ILL completely new.TRA-be.born.2SG

'If you go to a spa, you will get (completely) rejuvenated (lit. revived).'

The particle újra always means that the process starts from scratch or at least is substantially repeated (and it is not the case that a previous result is slightly modified), therefore the particles cannot be freely switched in the previous examples. While (44) is quite good, although with a perhaps a slightly different reading than before, (45) is infelicitous as one needs to start a new life for the verb 'be reborn' to be used in a context.

Az ember egyes vallások szerint a halál után újjá-születik. the person some religion.PL according.to the death after new.TRA-be.born.3SG 'According to some religions, one is revived after death.'

$$
\begin{aligned}
& \text { \#Ha elmész egy gyógyfürdőbe, (teljesen) újra-születsz. } \\
& \text { if away.go.2SG a health.spa.ILL completely again-be.born.2SG } \\
& \text { 'If you go to a spa, you (will) get (completely) reborn.' }
\end{aligned}
$$

To sum up, these examples have shown that the distribution of újra with respect to a different resultative form based on the same adjective as the one in this particle confirms that its meaning is not compositional, therefore it is different from a regular, lexical secondary predicate, as well as from directional particles shown in the previous subsections.

\subsection{The syntax of the particle újra}

With the previous empirical distinctions in mind, we can clearly state that the use of ujra under investigation warrants its analysis as a verbal particle, albeit one that distinguishes it from typical, directional particles, as will be proposed in this section.

Verbal particles have been often treated as a separate word class. They are different from regular goal-denoting PPs and secondary predicates in that their meaning is less lexical, more 
grammaticalized and that they are used relatively productively in their grammaticalized function. When descriptive-historical grammars consider the word class of verbal particles, e.g. in Hungarian, these characteristics are decisive (e.g. D. Mátai 2011, see also Kiefer \& Ladányi 2000).

However, it has been argued for various languages, including Hungarian, that we can integrate particles into an extended adpositional phrase, i.e., particles do not constitute a separate syntactic category (or word class), they are adpositional in their categorial specifications (see Asbury et al. 2007; Hegedús 2013 a.o. for Hungarian). Particles are in fact functional adpositions, occupying a head in the extended projection of the $\mathrm{PP}$, dubbed here as $p \mathrm{P}$ (following Svenonius 2010, among others).

When it comes to the syntactic structure of the clause involving a particle, the general assumption is that particles are merged as secondary predicates in the VP, as argued by É. Kiss (2004, 2006) for Hungarian. ${ }^{7}$ Hegedüs (2013) introduces particles-arguing mostly for directional particles-under $\mathrm{V}$ as functional heads within a complement $p \mathrm{P}$ (in fact, as a type of relator, in the sense of Den Dikken 2006) and unifies the structure of particles and resultative secondary predicates in that both of them are complement $p$ Ps (46). In recent generative syntactic literature, particles as predicative $p$ heads have been argued to have a subject in Spec, $p \mathrm{P}$ (e.g. Svenonius 2006, 2010).

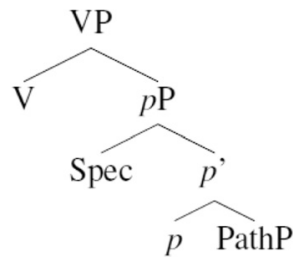

During the derivation, the $p \mathrm{P}$ moves into a functional projection to form a complex predicate with the verb (and as a part of deriving the aspectual properties of the event). I follow Surányi $(2009 \mathrm{a}, 2009 \mathrm{~b})$ in assuming that the locus of this is in a low functional projection below vP, i.e. below the merge point of the external argument, here dubbed as PredP (also following Hegedüs 2013 for the specific structure of the particle; but see also É. Kiss 2006 for complex predicate formation in a different hierarchical position), and the verb moves up to the Pred. The particle moves as a phrase, but the internal argument and the potential lexical complement of the particle are evacuated before this movement (as any other analysis has to assume that posits that particle movement is phrasal movement).

${ }^{7}$ Surányi (2009b) shows that particles can be adjuncts in the clause in some cases, but many of them are secondary predicates. 


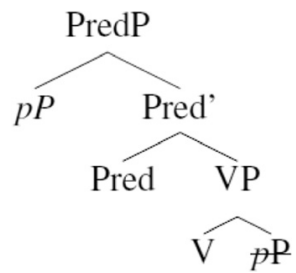

This is the general structure for verbal particles, deriving their pre-verbal position from a lower base position. ${ }^{8}$ However, looking at the structural properties of a group of derived particle verbs and their distribution with respect to resultative predicates, Hegedüs \& Dékány (2017) argue that a subgroup of Hungarian particles are in fact not introduced under $\mathrm{V}$ but are generated higher in the structure, in the position where the other particles move to. The properties of verbal particle újra give further support to the claim that not all particles are created equal in the clause, and I assume that it differs from regular, directional particles in exactly this property: it is not introduced into the structure in the argument structure within VP but as a predicate modifier in the position that other verbal particles reach by movement.

Verbal particle ujra, thus, belongs to the group of particles that are not secondary predicates in the complement of V, which also fits in with Kiefer \& Ladányi's (2000) semantic characterization of this particle, even though they do not associate a specific syntactic structure with the semantic properties. Kiefer \& Ladányi (2000) look at the semantic typology of verbal particles in Hungarian and include particle újra in their discussion, characterizing it as a predicate with one argument (as opposed to, e.g. directional, particles that are dyadic predicates), and its only argument is the verb(al expression), which I assume to translate to syntax as the verbal particle not being a secondary predicate but a predicate modifier, here inserted in Spec,PredP into the structure.

The structure I propose is the one given in (48). There is a restriction as we have seen from the data that the VP has to include an internal argument, but it is not directly related to the particle in the structure, contrary to the case of those particles that are introduced as secondary predicates under $\mathrm{V}$ as in (46). During the derivation the verb moves up the Pred head, whose specifier the particle occupies, and the verb and the particle form a complex predicate (Surányi 2009a, 2009b).

\footnotetext{
${ }^{8}$ Surányi $(2009 a, 2009 b)$ further assumes that there is one more step in the derivation of the neutral surface order, namely, VMs (including verbal particles) move into Spec,TP and the verb moves into T. This further movement does not seem to play a role in the present account, therefore, while I follow Surányi in assuming that this movement takes place, it is not illustrated above.
} 


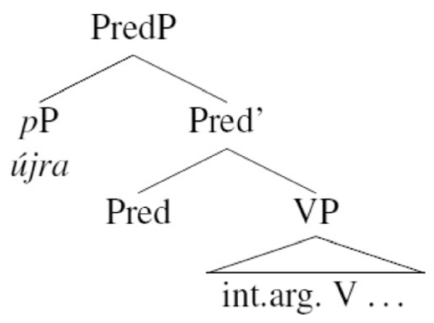

The particle is within a $p \mathrm{P}$, categorially it is adpositional. The directional particles have been proposed to be $p$ heads (e.g. (46), see also Hegedüs 2013; Dékány \& Hegedús 2015 a.o.), while the newly developing particles start out from being internally complex phrases and are reanalyzed as heads after they undergo grammaticalization (cf. Hegedüs 2015.)

Let me close this section with a note on the restitutive reading. It has been argued that a repetitive modifier modifies the result state when it has a restitutive reading (von Stechow 1996). In syntactic terms this amounts to saying that it is introduced under $\mathrm{V}$ into the structure if we take standard analyses of resultatives either in terms of Small Clause results (e.g. Hoekstra 1988), or in a decomposed argument structure (e.g. Ramchand 2008). Von Stechow's (1996) general syntactic point is that the restitutive reading is available as long as the adverb is introduced into the structure under the agent (under VoiceP in his analysis). Here, I have proposed an analysis of the verbal particle use of ujra (which does not necessarily have to say much about the restitutive reading of the adverb újra) where the particle is merged above the VP but crucially lower than the external argument. The latter point still ensures that a restitutive reading excluding the agent is always available, which seems to be the correct prediction. The fact that it is in Spec,PredP, the assumed locus of complex predicate formation with the verb makes it a verbal particle, as opposed to an adverb.

This proposal raises (at least) two issues: one is related to the properties of the other verbal particle with a type of repetitive meaning in Hungarian, the other issue is related to the relatively unorthodox syntactic structure for a verbal particle and whether it is motivated in general. These will be dealt with in the next section.

\section{TWO MERGE POSITIONS FOR HUNGARIAN VERBAL PARTICLES}

\subsection{The particle vissza 'back'}

4.1.1. The syntactic properties of the counterdirectional particle. When repetitive elements are discussed, reversing direction (as opposed to reversing result) must also be included. Counterdirectionality is generally subsumed under the larger group of 'repetitive' meanings, and there are languages where the same lexical element that has a repetitive or a restutitive meaning can express movement backwards, i.e., counterdirectionality, as well. Patel-Grosz \& Beck (2014) argue that Kutchi Gujarati is a language that lexicalizes all these meanings with the same element, pacho 'again'. This is not the case in Hungarian. While some repetitive elements have restitutive readings as well (megint and újra 'again'), only one of them can express counterdirectionality. The verbal particle vissza 'back', a directional element, 
morphologically completely different from megint and újra, lexicalizes this meaning, illustrated in (49).

a. Mari vissza-ment a ház-ba. Mari back-go.PST.3SG the house-ILL

'Mari went back into the house.'

b. A hömérséklet vissza-esett (10 fok-ra).

the temperature back-fall.PST.3SG 10 degree-sUB

'The temperature dropped back down (to 10 degrees).'

In present-day Hungarian, this is the only productive element for counterdirectionality. To a very limited extent the particle meg is also found in counterdirectional contexts (50), but it is no longer productive in this meaning, it has almost fully grammaticalized by now into a simple telicizing functional element. ${ }^{9}$
a. Mari meg-adta
a pénzét
Péter-nek.
Mary back-give.PST.DEFOBJ.3SG the money.POSS.3SG.ACC Peter-DAT
'Mary returned Peter his money.'
b. Mari meg-jött a kirándulás-ról.
Mary back-come.PST.3SG the excursion-DEL
'Mary arrived back from the excursion.'

The particle verb meg-ad 'back-give' can only be used for returning borrowed money, that is its lexicalized meaning, and it cannot be used with a book as the object (51). There the productive vissza can express counterdirectionality.
a. *Mari meg-adta
a könyvet Péter-nek.
Mary back-give.PST.DEFOBJ.3SG the book.ACC Peter-DAT
'Mary gave the book back to Peter.'
b. Mari vissza-adta a könyvet Péter-nek.
Mary back-give.PST.DEFOBJ.3SG the book.ACC Peter-DAT
'Mary gave the book back to Peter.'

When motion is involved, e.g. with transaction verbs, sometimes either újra or vissza can appear as the particle (with the restrictions mentioned above for újra) in the same clause, but there is a constant semantic difference. Újra has a restitutive interpretation, while vissza is counterdirectional, the examples in (52) and (53) are a relevant minimal pair to show this division of labor between the two particles.

\footnotetext{
${ }^{9}$ On the history of Hungarian particles, see e.g. D. Mátai $(1989,1991)$; and see Forgács (2004) on productive grammaticalization patterns of Hungarian verbal particles, as well as Hegedüs $(2014,2015)$ on structural changes in the Hungarian $p \mathrm{P}$.
} 

Péter újra-küldte
az emailt Mari-nak.
Peter again-send.PST.DEFOBJ.3SG the email.ACC Mary-DAT
'Peter resent the email to Mary.'
Péter vissza-küldte
az emailt Mari-nak.
Peter back-send.PST.DEFOBJ.3SG the email.ACC Mary-DAT
'Peter sent the email back to Mary.'

There is an important distributional difference between the two particles. Unlike the particle ujra, vissza can introduce an internal argument and be the endpoint resultative predicate in a complex event (54), which means that it behaves on par with regular verbal particles and terminative or resultative secondary predicates. In these examples, the particle-less verb is an unergative one but here it is a part of a complex event with a result state included.
a. Mindenki vissza-sírja
az előzo”
fönököt.
everyone back-cry.DEFOBJ.3SG the previous boss.ACC
'Everyone wishes for the previous boss to be back.'
b. A közönség vissza-tapsolta a zenekart. the audience back-clap.PST.DEFOBJ.3SG the band.ACC 'The audience applauded until the band came back.'

Based on these properties, we can say that vissza 'back' is a directional adposition whose meaning specification includes counterdirectionality and as such it is a functional adposition. Structurally it means that we are dealing with a $p$ element within an extended adpositional phrase. The particle is the functional head that introduces the Figure, the internal argument in a complex event, into the structure. Thus, from the two possible syntactic structures for verbal particles given in Section 3.4, in this case, we have a structure where $p \mathrm{P}$ is is introduced into the clause as the complement of $\mathrm{V}$ (55). The PathP complement to vissza as a $p$ head is not always lexicalized, but it can be, as in (53), where I assume the dative to be in PathP and specifying the endpoint.

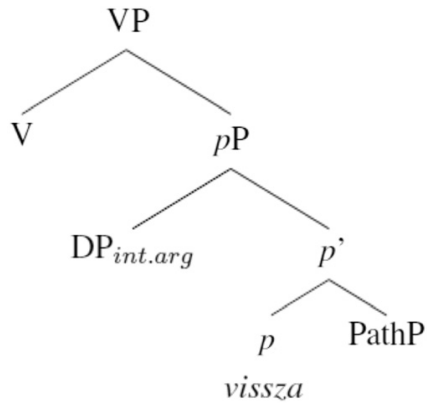


In overt syntax, the particle moves into the preverbal field, as do all particles, as discussed in Section 3.4. I assume, as before, that this movement is into Spec, PredP and that the verb moves into Pred. With this movement of the particle, we derive the same configuration that we had earlier in the case of the particle újra 'again', only in that case it was argued to be the base position of the particle, while it is a derived position here.

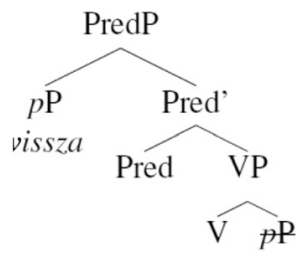

4.1.2. Limited restitutive use of vissza 'back'. As far as its interpretational possibilities are concerned, vissza is generally ungrammatical in restitutive function without directed motion involved. Sometimes the directionality of the event is introduced by the particle, as in (54), and also in the examples in (57). Here we see that directional particles do not only telicize the event but add some directionality to the already dynamic event, they create a complex motion event as locking the door can be construed as movement back, in or out.
a. Mari vissza-zárta
az ajtót.
Mary back-lock.PST.DEFOBJ.3SG the door.ACC
'Mary locked the door back.'
b. Mari be-zárta az ajtót.
Mary into-lock.PST.DEFOBJ.3SG the door.ACC
'Mary locked the door.'
c. Mari ki-zárta az ajtót.
Mary out-lock.PST.DEFOBJ.3SG the door.ACC
'Mary unlocked the door.'

However, there seem to be some contexts where vissza can be simply restitutive without there being a spatial meaning, and, therefore, directionality involved. In one set of cases, we are dealing with unaccusative verbs involving vissza as a restitutive particle (58). ${ }^{10}$ It is hard to identify directionality in the semantics of this case, the particle seems purely restitutive. The English translations show that (58a) uses a motion verb and the counterdirectional element, while the other constructions are translated with the repetitive adverb again to provide the equivalent meanings with such change-of-state verbs.

\footnotetext{
${ }^{10} \mathrm{I}$ thank one of the anonymous reviewers for suggesting some of the verbs illustrated in these examples.
} 

a. Anna korán fel-ébredt, de még vissza-aludt.
Anna early up-wake.PST.3SG but still back-sleep.PST.3SG
'Anna woke up early but went back to sleep still.'

b. Öntözés után a levelek vissza-zöldültek.

watering after the leaf.PL back-green.VRB.PST.3PL

'After watering, the leaves turned back to green.'

c. Sokáig tart, míg a fém vissza-keményedik.

long.TER last.3SG while the metal back-harden.3SG

'It takes a long time for the metal to become hard again.'

The other context is even more curious and seems to be a rare example of a transitive verb with $v i s s z a$ as a restitutive particle (59). The verb here is tanul 'learn' and the complex meaning of the particle verb may be paraphrased as 'bringing back an old habit, custom, knowledge by learning it again (esp. by a new generation)', but this also seems to be a good candidate for a purely restitutive meaning of the generally counterdirectional particle. An Internet search finds quite a few hits, and the Gigaword Corpus of Hungarian also contains some examples for this particleverb (59).
hogy meg-tanulják, hogy vissza-tanulják, saját kultúrájuk részét
that PERF-learn.3PL that back-learn.3PL own culture.POSS.3PL part.ACC
'so that they learn, they re-acquire, part of their own culture'
(radio program, Hungarian Gigaword Corpus, Oravecz et al. 2014)

This use, where directionality is very hard or impossible to find and a restitutive reading seems to be the appropriate one, is scarce for now. It may easily be the case that there is a slow change towards the counterdirectional element becoming restitutive by grammaticalizing into a nondirectional functional particle. ${ }^{11}$ For now, the main use of the particle is to encode counterdirectionality, and it is the only productive verbal particle for that semantic content.

\section{2. Újra is not the only verbal particle inserted above VP}

Hegedüs \& Dékány (2017) argue for the existence of a group of verbal particles that are not introduced into the structure under $\mathrm{V}$ on the basis of their compatibility with some particle verbs that involve what they call inseparable verbal particles. They show that there are some particle verbs whose particle is inseparable from the verb - in sharp contrast with the fact that Hungarian particles are separable in general. However, these particles are all in fact "trapped" in a multiply derived verb, so Hegedüs \& Dékány (2017) argue that these particles cannot be moved

\footnotetext{
${ }^{11}$ This is hardly without precedent. In fact, the particle meg, which has no lexical meaning now, has undergone a full grammaticalization process from being a directional postposition (still identifiable in PPs, such as ház mögé 'the house behind.to'), to being a counterdirectional particle (fossilized in particle verbs such as the ones in (50)), to a semantically bleached perfectivezer (Hegedüs 2014, 2015; D. Mátai 1989, 1991). A couple of repetitive adverbs today are originally complex forms involving this particle (adverb): megint 'again'- which also has a restitutive use -, and ismét (>ismeg) 'again'. This indicates that we are dealing with a cyclical change, and it may easily be the case that vissza 'back' has also begun a grammaticalization process but if that is the case, we are witnessing the beginnings of the path.
} 
out of a phasal nominalization layer, but they are still visible for syntax to some extent. Verbs such as the ones in (60) are involved (for a full list, see Hegedüs \& Dékány 2017, (12)).
a. ki-fog-ás-ol; be-foly-ás-ol;
out-hold-NOM-VRB; in-flow-NOM-VRB;
'take objection to; influence;'
b. fel-té-t-el-ez; fel-vé-t-el-i-z(-ik);
up-put-NOM-NOM-VRB; up-take-NOM-NOM-NOM-VRB
'assume; take an entrance exam'

Despite being inseparable, the particles in these derived verbs are to some extent visible for syntax as these verbs generally cannot co-occur with another particle or with another type of VM.
a. János $\left(* \mathrm{el} / *^{*} \mathrm{ki} / *^{*} \mathrm{meg}\right)$-befolyásolta
Marit.
John (away/out/PRT)-influence.PST.3SG.DEF Mary.ACC
'John (successfully) influenced Mary.'
(Hegedüs \& Dékány 2017, (17))
a szemem.
red.sUB up-entrance.exam.take.PST.1SG the eye.POSS.1SG.ACC
b. *Vörösre fel-vételiztem
'I got red eyes by taking entrance exams/an entrance exam.'
(Hegedüs \& Dékány 2017, (24))

However, this is not exceptionless, these verbs are compatible with some verbal particles and resultative phrases. Among the VMs that can co-occur with derived particle verbs, we can find particles and some resultatives, which could be characterized as idiomatic, following Forgács (2004), as they are not used in their original, lexical-compositional sense.
a. Szét-fel-vételiztem az agyam. apart-up-exam.take.PST.1SG the brain.POSS.1SG.ACC 'I got exhausted with taking entrance exams.' (Hegedüs \& Dékány 2017, (20b))
b. Halálra/betegre/agyon fel-vételiztem magam. death.sUB/sick.suB/to.death up-exam.take.PST.1SG self.POSS.1SG.ACC 'I got myself sick by taking entrance exams.' (Hegedüs \& Dékány 2017, (26))

Hegedüs \& Dékány (2017) claim that those particles and (idiomatic) resultative phrases that these verbs with inseparable particles can combine with are generated in the specifier position that the other particles move into during the derivation, i.e. they are syntactically different from the other (directional) particles. This is supported by the semantic properties of these elements as they are not directional but express that an eventuality can be characterized as being completed 'to a full or an extreme degree'.

Although not discussed by Hegedüs \& Dékány (2017), the verbal particle újra fits in with this group of particles, as far as its distribution is concerned. The particles/resultatives they discuss are different from újra, however, in that they can introduce their own theme into the argument structure, as in (62), while újra cannot. 
The examples in (63) and (64) show that újra is compatible with the verbs under discussion and the meaning differences between the (a) and the (b) examples show that we are not always dealing with the adverb újra since there is a meaning difference between having the particle or the adverb in the clause. Including the particle in (63a) implies that Mary (or someone else, as a restitutive reading seems available) was not admitted to the university at the earlier event of applying, while the adverb does not have such an implication. In (64a), the same item was entered again as income, while with the adverb this is not necessarily the case, the adverb can have higher scope than the indefinite.
a. Mari újra-felvételizett
az egyetem-re.
'Mary re-applied to the university.'
Mary again-up.exam.take.PST.3SG the university-SUB
b. Mari újra felvételizett az egyetem-re.
Mary again up.exam.take.PST.3SG the university-SUB
'Mary applied to the university again.'
a. Péter újra-bevételezett
Peter again-into.enter.income.PST.3SG an item.ACC
'Peter re-entered an item as income.'
b. Péter újra bevételezett egy tételt.
Peter again into.enter.income.PST.3SG an item.ACC
'Peter entered an item as income again.'

This compatibility suggests that the group of verbal particles not generated as secondary predicates in the complement of $\mathrm{V}$ does not only comprise elements referring to full or extreme degree but it also includes the restitutive particle. This also means that it is not a unique property of ujra to be generated in a different position than directional verbal particles are, although they do not share all their syntactic properties. At the same time, as we saw, the counterdirectional verbal particle patterns with directional particles not only semantically but also syntactically.

\section{CONCLUSION}

There are two main points this paper has attempted to make. One is that the Hungarian repetitive element újra 'again' has a verbal particle use, in which case it is merged into the structure in the position where verbal particles form a complex predicate with the verb in overt syntax, analyzed here as Spec, PredP. This means that it is structurally different from the adverb újra, even though the adverb also has a restitutive reading when it is low enough in the structure. That is, the same restitutive interpretation can be encoded with an adverb or with a verbal particle, but in the latter case, the verbal particle also contributes telicity as other particles do, while not introducing a theme argument, contrary to (most) other verbal particles. In general its use is more restricted than that of many other particles, but it is obviously distinct from the adverb as well.

The structure proposed accounts for the differences between the verbal particle újra and other, mostly directional verbal particles that introduce their own subjects as an internal 
argument in the argument structure of a complex event. Among those directional verbal particles is the counterdirectional repetitive particle vissza 'back'. This counterdirectional particle is a secondary predicate merged under $\mathrm{V}$ and moved into its preverbal position in overt syntax, making the two repetitive particles rather distinct not only semantically but also syntactically.

If this analysis is on the right track, it also supports proposals that Hungarian verbal particles can be introduced into the syntactic structure in (at least) two positions, as proposed by Hegedüs \& Dékány (2017). Since both újra as a particle and the other elements assumed to be merged immediately preverbally are recently developed (or still not fully grammaticalized) verbal particles, a new question arises with respect to the possible source positions and grammaticalizations paths of various verbal particles both in Hungarian and cross-linguistically. Related to this issue is the syntactic, semantic and also diachronic connection between modification of a result state and being or becoming a resultative predicate, which opens the door to finding the syntactic connection between the adverb use and the particle use of ujra discussed here. These are open issues, left for future research.

\section{REFERENCES}

Asbury, Anna, Berit Gehrke \& Veronika Hegedüs. 2007. One size fits all: Prefixes, particles, adpositions and cases as members of the category P. In Cem Keskin (ed.), UiL-OTS Yearbook 2006. Utrecht: UiL-OTS, 1-17.

Beck, Sigrid. 2005. There and back again: A semantic analysis. Journal of Semantics 22. 3-51.

Csirmaz, Aniko. 2015. Re Hungarian again. Acta Linguistica Hungarica 62(3). 263-295.

D. Mátai, Mária. 1989. Igekötőrendszerünk történetéből [From the history of our class of verbal particle]. Magyar nyelv 85(1). 9-28.

D. Mátai, Mária. 1991. Az igekötők [Verbal particles]. In Loránd Benkő, Erzsébet E. Abaffy \& Endre Rácz (eds.), A magyar nyelv történeti nyelvtana 1: A korai ómagyar kor és elözményei. Budapest: Akadémiai Kiadó, 433-441.

D. Mátai, Mária. 2011. Magyar szófajtörténet [History of Hungarian word classes]. Budapest: Argumentum Kiadó.

Dékány, Éva \& Veronika Hegedüs. 2015. Word order variation in Hungarian PPs. In Katalin É. Kiss, Balázs Surányi \& Éva Dékány (eds.), Approaches to Hungarian 14: Papers from the Piliscsaba Conference. Amsterdam: John Benjamins, 95-120.

Den Dikken, Marcel. 2006. Relators and linkers: the syntax of predication, predicate inversion, and copulas. Cambridge, MA: The MIT Press.

É. Kiss, Katalin. 2002. The Syntax of Hungarian. Cambridge: Cambridge University Press.

É. Kiss, Katalin. 2004. Egy igekötőelmélet vázlata [Outline of a theory of the verbal particle]. Magyar nyelv 50. $15-43$.

É. Kiss, Katalin. 2006. The function and the syntax of the verbal particle. In Katalin É. Kiss (ed.), Event Structure and the Left Periphery. Studies on Hungarian. Dordrecht: Springer, 17-55.

Fabricius-Hansen, Catherine. 2001. Wi(e)der and again(st). In Caroline Féry \& Wolfgang Sternefeld (eds.), Auditur vox sapientiae: A Festschrift for Arnim von Stechow. Berlin: Akademie Verlag, 101-130.

Forgács, Tamás. 2004. Grammaticalisation and preverbs. Acta Linguistica Hungarica 51(1-2). 45-84. Hegedüs, Veronika. 2013. Non-verbal predicates and predicate movement in Hungarian. Tilburg University dissertation. Utrecht: LOT. 
Hegedüs, Veronika. 2014. The cyclical development of Ps in Hungarian. In Katalin É. Kiss (ed.), The evolution of functional left peripheries in Hungarian syntax. Oxford: Oxford University Press, 122-147.

Hegedüs, Veronika. 2015. The grammaticalization of postpositions in Old Hungarian. In George Walkden \& Theresa Biberauer (eds.), Syntax over Time. Oxford: Oxford University Press, 72-85.

Hegedűs, Veronika \& Éva Dékány. 2017. Two positions for verbal modifiers: Evidence from derived particle verbs. In Anikó Lipták \& Harry van der Hulst (eds.), Approaches to Hungarian. Volume 15. Papers from the 2015 Leiden Conference. Amsterdam: John Benjamins, 65-94.

Hoekstra, Teun. 1988. Small clause results. Lingua 74. 101-139.

Horn, Laurence R. 1980. Affixation and the unaccusative hypothesis. Chicago Linguistic Society 16. 134-146.

Horvath, Julia \& Tal Siloni. 2011. Causatives across components. Natural Language and Linguistic Theory 29. 657-704.

Kálmán, László. 1985. Word order in neutral sentences. In István Kenesei (ed.), Approaches to Hungarian 1. Szeged: JATE, 13-23.

Kardos, Éva. 2016. Telicity marking in Hungarian. Glossa: A Journal of Generative Linguistics 1. 1-37.

Kiefer, Ference \& Mária Ladányi. 2000. Az igekötők [Verbal particles]. In Ferenc Kiefer (ed.), Strukturális magyar nyelvtan 3. Morfológia. Budapest: Akadémiai Kiadó, 453-518.

Levin, Beth \& Malka Rappaport Hovav. 1995. Unaccusativity: At the syntax-lexical semantics interface. Cambridge, MA: MIT Press.

Marantz, Alec. 2007. Restitutive re- and the first phase of syntax/semantics of the VP. Manuscript, New York University.

Oravecz, Csaba, Tamás Váradi \& Bálint Sass. 2014. The Hungarian Gigaword corpus. In Nicoletta Calzolari, Khalid Choukri, Thierry Declerck, Hrafn Loftsson, Bente Maegaard, Joseph Mariani, Asuncion Moreno, Jan Odijk and Stelios Piperidis (eds.), Proceedings of LREC 2014, Reykjavik: ELRA, 1719-1723.

Patel-Grosz, Pritty \& Sigrid Beck. 2014. Revisiting again: The view from Kutchi Gujarati. In Proceedings of Sinn und Bedeutung 18, 303-321. Retrieved from https://ojs.ub.uni-konstanz.de/sub/index.php/sub/ article/view/319

Ramchand, Gillian. 2008. Verb Meaning and the Lexicon. A first phase syntax. Cambridge: Cambridge University Press.

Stechow, Arnim von. 1996. The different readings of wieder 'again': A structural account. Journal of Semantics 13. 87-138.

Surányi, Balázs. 2009a. "Incorporated” locative adverbials in Hungarian. In Katalin É. Kiss (ed.), Adverbs and adverbial adjuncts at the interfaces. Berlin: Mouton de Gruyter, 39-74.

Surányi, Balázs. 2009b. Verbal particles inside and outside vP. Acta Linguistica Hungarica 56(2-3). 201-249.

Svenonius, Peter. 2006. P: Anatomy of a category. Manuscript. University of Tromsoe.

Svenonius, Peter. 2010. Spatial prepositions in English. In Guglielmo Cinque \& Luigi Rizzi (eds.), Mapping spatial PPs. Oxford: Oxford University Press, 127-160.

Open Access. This is an open-access article distributed under the terms of the Creative Commons Attribution 4.0 International License (https://creativecommons.org/licenses/by/4.0), which permits unrestricted use, distribution, and reproduction in any medium, provided the original author and source are credited, a link to the CC License is provided, and changes - if any - are indicated. (SID_1) 